\title{
PENGARUH RETURN ON EQUITY (ROE), DEBT TO EQUITY \\ RATIO (DER), PRICE EARNING RATIO (PER), DAN BOOK VALUE PER SHARE (BVS) TERHADAP NILAI PERUSAHAAN PADA SEKTOR PERBANKAN YANG TERDAFTAR DI BEI PERIODE 2013-2017
}

\author{
Victoria Monica Rosana, Karnadi, Idham Lakoni \\ Fakultas Ekonomi, Jurusan Manajemen \\ Universitas Prof. Dr. Hazairin, SH. Bengkulu \\ Email : monicaunin@gmail.com
}

\begin{abstract}
ABSTRAK
Penelitian ini bertujuan untuk menguji pengaruh Return On Equity (ROE), Debt to Equity Ratio (DER), Price Earning Ratio (PER), dan Book Value per Share (BVS) baik secara parsial dan simultan terhadap nilai perusahaan pada sektor perbankan yang terdaftar di BEI periode 2013-2017. Populasi dalam penelitian ini adalah seluruh perbankan yang terdaftar di BEI, sampel dipilih menggunakan teknik pengambilan sampling purposive sampling dan diperoleh sampel sebanyak 5 perbankan. Metode analisis dalam pengujian ini menggunakan analisisi regresi linear berganda. Hasil dari penelitian ini menunjukkan bahwa secara parsial ROE dan PER berpengaruh positif signifikan terhadap nilai perusahaan, sedangkan DER dan BVS berpengaruh negativ signifikan terhadap nilai perusahaan. Tetapi secara simultan ROE, DER, PER, dan BVS berpengaruh positif signifikan terhadap nilai perusahaan.
\end{abstract}

Kata Kunci : ROE, DER, PER, BVS, dan Nilai Perusahaan

\begin{abstract}
This study aims to examine the effect of Return on Equity (ROE), Debt to Equity Ratio (DER), Price Earning Ratio (PER), and Book Value per Share (BVS) both partially and simultaneously to the firm value of the banking sector listed in IDX for the period 20132017. The population in this study were all banks listed on the IDX, samples were selected using purposive sampling sampling technique and obtained a sample of 5 banks. The analysis method in this test uses multiple linear regression analysis. The results of this study indicate that partially ROE and PER have a significant positive effect on firm value, while DER and BVS have a significant negative effect on firm value. But simultaneously ROE, DER, PER, and BVS have a significant positive effect on firm value.
\end{abstract}

Keywords: ROE, DER, PER, BVS, dan Nilai Perusahaan 


\section{PENDAHULUAN}

Menurut Undang-undang No. 8 Tahun 1995 tentang pasar modal adalah pasar yang dikelola secara terorganisi dengan aktivitas perdagangan surat berharga, seperti saham, obligasi, option waran, right, dengan menggunakan jasa perantara komisioner dan underwriter (penjamin). Pada aktivitasnya pasar modal mempunyai fungsi sebagai pihak yang memberikan sarana dalam mengalihkan dana dari pihak yang memiliki kelebihan dana (investor) terhadap pihak yang membutuhkan dana (emiten). Untuk investor pemula yang baru masuk kedalam dunia pasar modal harus mempelajari tentang menganalisis atau menilai suatu perusahaan itu baik atau tidak, untuk dijadikan sarana investasi. Sehingga bagi perusahaan, nilai perusahaan menjadi tujuan utama dari manajemen keuangan perusahaan.

Nilai perusahaan adalah kondisi yang telah tercapai oleh suatu perusahaan, sebagai cerminan kepercayaan masyarakat kepada perusahaan setelah melalui proses selama beberapa tahun, semenjak perusahaan tersebut didirikan sampai sekarang. Meningkatnya nilai perusahaan merupakan suatu prestasi yang sesuai dengan keinginan pemilik, dan menggambarkan tolak ukur kinerja manajemen perusahaan tersebut.

Return On Equity (ROE) sering disebut laba atas ekuitas, atau rasio yang mampu menggambarkan seberapa besar kontribusi modal dalam menciptakan laba bersih. Laba yang diperoleh dapat mempengaruhi minat para investor untuk menginvestasikan dananya ke perusahaan yang dianggap dapat memberikan keuntungan. Semakin banyak investor yang ingin meningvestasikan dananya, maka dengan sendirinya nilai perusahaan akan meningkat baik.

Debt to Equity Ratio (DER) juga bisa disebut kemampuan perusahaan dalam memenuhi kewajibannya membayar hutang dengan jaminan modal sendiri. Seandainya nilai DER rendah, artinya perusahaan mampu membayar kewajibannya maka dapat dikatakan nilai perusahaan itu baik. Sebaliknya, jika nilainya semakin tinggi maka semakin beresiko bagi perusahaan (kemungkinan perusahaan tidak dapat membayar semua hutangnya). (Fahmi, 2015:73).

Price Earning Ratio (PER) adalah salah satu rasio penilai bagi kebanyakan investor dalam melihat pertumbuhan suatu perusahaan. PER merupakan rasio harga terhadap laba atau perbandingan harga pasar perlembar saham dengan laba perlembarnya. (Fahmi, 2015:83).

Book Value per Share (BVS) yang artinya menunjukkan aktiva bersih (net asset) yang dimiliki pemegang saham dengan memiliki satu lembar saham. (Jogiyanto, 2016:182).

Oleh karena itu, dari seluruh uraian pembahasan latar belakang diatas peneliti tertarik untuk melakukan penelitian dengan judul penelitian "Pengaruh Return On Equity (ROE), Debt To Equity Ratio (DER), Price Earning Ratio (PER), dan Book Value per Share (BVS) Terhadap Nilai Perusahaan Pada Sektor Perbankan Yang Terdaftar di BEI Periode 2013-2017." 


\section{TINJAUAN PUSTAKA}

\section{Return on Equity (ROE)}

Return On Equity (ROE) disebut juga dengan laba atas. Rasio ini membahas sejauh mana perusahaan mempergunakan sumber dayanya untuk memberikan laba atas modal sendiri, dan biasanya dinyatakan dalam bentuk persentase (\%). (Fahmi, 2015:82).

Rumus untuk mencari Return on Equtiy (ROE) dapat digunakan perhitungan sebagai berikut :

$$
\text { Return On Equity }(\mathrm{ROE})=\frac{\text { Earning After Interest and Tax }(E A T)}{\text { Shareholders Equity }} \times 100 \%
$$

\section{Debt to Equity Ratio (DER)}

Debt to Equity Ratio (DER) merupakan rasio yang membandingkan antara utang dengan ekuitas. Semakin tinggi nilai DER, maka semakin tinggi pula risiko kebangkrutan (Likuidasi) perusahaan. (Prihadi, 2012:163).

Rumus dalam mencari Debt To Equity Ratio (DER) dapat dihitung dengan perbandingan sebagai berikut :

$$
\text { Debt To Equity Ratio (DER) }=\frac{\text { TOTAL LIABILITIES }}{\text { TOTAL SHAREOLDERS } \text { EQUITY }^{\prime}} \text { X 100\% }
$$

\section{Price Earning Ratio (PER)}

Price Earning Ratio (PER) disebut juga rasio harga pada labanya, merupakan perbandingan harga pasar perlembar saham dengan laba perlembar saham. (Fahmi, 2015:83).

Rumus perhitungan untuk Price Earning Ratio (PER) dapat menggunakan perbandingan sebagai berikut :

$$
\text { Price Earning Ratio }(\mathrm{PER})=\frac{\text { Harga Per Saham }}{\text { Laba Per Saham }}
$$

\section{Book Value per Share (BVS)}

Book Value per Share (BVS) merupakan nilai buku per lembar saham yang menampilkan aktiva bersih (net asset) yang dimiliki pemegang saham dengan memiliki satu lembar saham. Oleh sebab itu, aktiva bersih dapat diartikan dengan total ekuitas, yang ditampilkan dengan membagi total ekuitas dengan jumlah saham yang beredar. (Jogiyanto, 2016:182).

Rumus untuk mencari nilai buku atau BVS dapat menggunakan perhitungan sebagai berikut :

$$
\text { Book Value per Share }(\mathrm{BVS})=\frac{\text { MODAL EKUITAS }}{\text { JUMLAH SAHAM BEREDAR }}
$$




\section{Nilai Perusahaan}

Nilai perusahaan disebut juga nilai pasar perusahaan, adalah harga yang dibayar oleh calon pembeli jika perusahaan tersebut dijual. (Husnan dan Pudjiastuti, 2015:6). Nilai ini menggambarkan keadaan yang telah dicapai suatu perusahaan sebagai cerminan kepercayaan masyarakat kepada perusahaan setelah melalui proses selama beberapa tahun sejak perusahaan tersebut didirikan sampai saat ini. Pada penelitian ini, nilai perusahaan dihitung dengan indikator PBV (Price Book Value).

Rumus untuk mencari PBV (Price Book Value) dapat digunakan perhitungan sebagai berikut :

Price Book Value $(\mathrm{PBV})=\frac{\text { MARKET PRICE PER SHARE }}{\text { BOOK VALUE PER SHARE }}$

\section{Kerangka Pemikiran}

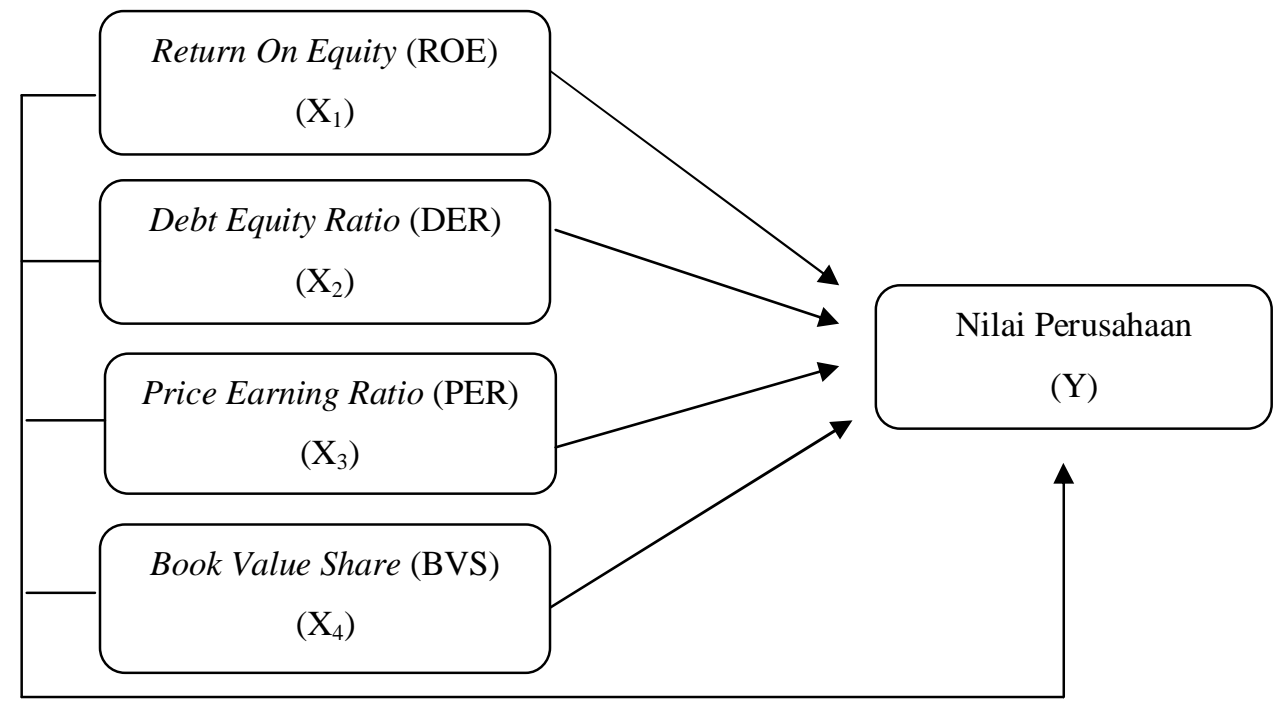

Dari gambar kerangka pemikiran diatas dapat jelaskan bahwa secara individu atau parsial, Return On Equity $\left(\mathrm{X}_{1}\right)$ berpengaruh terhadap nilai perusahaan (Y), Debt to Equity Ratio $\left(\mathrm{X}_{2}\right)$ berpengaruh terhadap nilai perusahaan $(\mathrm{Y})$, Price Earning Ratio $\left(\mathrm{X}_{3}\right)$ berpengaruh terhadap nilai perusahaan, dan Book Value per Share $\left(\mathrm{X}_{4}\right)$ berpengaruh terhadap nilai perusahaan (Y). Dan secara simultan menjelaskan bahwa, Return On Equity $\left(\mathrm{X}_{1}\right)$, Debt to Equity Ratio $\left(\mathrm{X}_{2}\right)$, Price Earning Ratio $\left(\mathrm{X}_{3}\right)$, dan Book Value per Share $\left(\mathrm{X}_{4}\right)$ berpengaruh terhadap nilai perusahaan $(\mathrm{Y})$.

\section{METODE PENELITIAN}

Sifat pada penelitian ini menggunakan asosiatif. Asosiatif adalah hubungan yang berupa sebab akibat, yang bertujuan untuk mencari hubungan antar variabel independen (variabel mempengaruhi) dan variabel dependen (variabel dipengaruhi). (Sugiyono, 2013:56). Pada penelitian ini terdapat 4 variabel independen (Return On Equity, Debt 
To Equity Ratio, Price Earning Ratio, Book Value per Share) dan variabel dependen (nilai perusahaan), yang akan diuji oleh peneliti apakah hipotesisnya benar atau salah, dengan menguji secara parsial maupun simultan.

Jenis data menggunakan dua jenis, yaitu kuantitatif dan kualitatif, data kuantitatif berupa laporan laba rugi dan neraca pada perusahaan sektor perbankan yang terdaftar di BEI periode 2013-2017 dan data kualitatif berupa teori kutipan buku, berbagai jurnal sebagai referensi, dan situs internet. Sumber data pada penelitian ini adalah skunder. Merupakan data penelitian yang didapat secara tidak langsung melalui pihak ke-3 (diperoleh dan di catat oleh pihak lain). (Sugiyono, 2014:131).

Sumber data dalam penelitian ini ialah data time series, yang berupa laporan keuangan (neraca dan laporan laba rugi) yang diperlukan peneliti pada perusahaan sektor perbankan yang terdaftar di Bursa Efek Indonesia periode 2013-2017 pada situs www.idx.co.id dan www.yahoofinance.com. Dalam penelitian ini populasinya adalah seluruh perusahaan sektor perbankan yang terdaftar di BEI periode 2013-2017, untuk sampel pada penelitian ini berjumlah lima perusahaan sektor perbankan yang terdaftar pada BEI di dalam indeks LQ45 periode 2013-2017, yaitu :

\section{TABEL II}

\section{PERUSAHAAN PERBANKAN DI DALAM INDEKS LQ 45}

\begin{tabular}{|c|l|c|}
\hline No & \multicolumn{1}{|c|}{ Nama Emiten } & Kode Saham \\
\hline 1 & Bank Central Asia Tbk & BBCA \\
\hline 2 & Bank Negara Indonesia Tbk & BBNI \\
\hline 3 & Bank Rakyat Indonesia Tbk & BBRI \\
\hline 4 & Bank Tabungan Negara Tbk & BBTN \\
\hline 5 & Bank Mandiri (Persero) Tbk & BMRI \\
\hline
\end{tabular}

Sumber : www.sahamok.com

Berikut ini adalah beberapa kriteria atau pertimbangan yang peneliti perlukan pada pengambilan sampel, yaitu sebagai berikut :

TABEL III

KRITERIA PENGAMBILAN SAMPLING

\begin{tabular}{|c|l|c|}
\hline No & \multicolumn{1}{|c|}{ Kriteria Pengambilan Sampling } & Kode Bank \\
\hline 1 & $\begin{array}{l}\text { Perusahaan sektor perbankan yang masuk di dalam } \\
\text { indeks LQ 45 }\end{array}$ & $\begin{array}{c}\text { BBCA, BMRI, } \\
\text { BBNI, BBTN, } \\
\text { BJBR, dan BBRI }\end{array}$ \\
\hline 2 & $\begin{array}{l}\text { Perbankan yang keluar dari indeks LQ 45 pada tahun } \\
2013\end{array}$ & BJBR \\
\hline 3 & $\begin{array}{l}\text { Perusahaan sektor perbankan yang memberikan } \\
\text { laporan keuangan yang diperlukan peneliti pada } \\
\text { periode 2013-2017 di LQ45 }\end{array}$ & $\begin{array}{c}\text { BBCA, BMRI, } \\
\text { BBNI, BBTN, dan } \\
\text { BBRI }\end{array}$ \\
\hline 4 & $\begin{array}{l}\text { Perusahaan sektor perbankan yang selalu liquid di } \\
\text { indeks LQ 45 periode 2013-2017 }\end{array}$ & \begin{tabular}{c} 
B \\
\hline
\end{tabular}
\end{tabular}

Sumber : www.sahamok.com 


\section{Metode Analisis}

\section{a. Analisis Regresi Linear Berganda}

Analisis regresi berganda untuk melihat seberapa besar pengaruh ROE, (X1), DER (X2), PER (X3), dan BVS (X4) terhadap Nilai Perusahaan (Y) pada sektor perbankan yang terdaftar di Bei periode 2013-2017.

\section{b. Analisis Korelasi}

Dalam analisis korelasi yang dicari adalah koefisien korelasi yaitu angka yang menjelaskan tingkat hubungan antara variabel independen (X) dengan variabel dependen (Y) atau untuk dapat mengetahui seberapa kuat lemahnya hubungan antara variabel independen dengan dependen.

\section{Analisis Korelasi Parsial}

Analisis ini berfungsi agar dapat mengetahui seberapa kuat hubungan korelasi antara kedua variabel dimana variabel lainnya dianggap berpengaruh atau dibuat tetap. Variabel yang diteliti menggunakan teknik statistik yaitu Pearson Product Moment (Sugiyono, 2013:248).

\section{Analisis Korelasi Berganda (Simultan)}

Analisis korelasi berganda digunakan untuk mengetahui kekuatan hubungan antara semua variabel bebas terhadap variabel terikat secara bersamaan. (Sugiyono, 2013:256). Uji ini bisa dilihat pada hasil output SPSS yang terletak pada tabel correlations.

\section{c. Uji Koefisien Determinasi $\left(\mathbf{r}^{2}\right)$}

Koefisien determinasi disimbolkan dengan $r^{2}$, yang menjadi pengukurr seberapa besar kemampuan model dalam menerangkan variabel dependen.

\section{d. Uji t (Uji Parsial)}

Uji $\mathrm{t}$ berfungsi sebagai pengujian koefisien korelasi parsial, pengujian ini dilakukanagar dapar mengetahui signifikan posisi secara parsial antara variabel independen terhadap variabel dependen.

e. Uji F

Uji F merupakan pengujian untuk koefisien korelasi berganda digunakan untuk menguji pengaruh Return On Equity $\left(\mathrm{X}_{1}\right)$, Debt to Equity Ratio $\left(\mathrm{X}_{2}\right)$, Price Earning Ratio $\left(\mathrm{X}_{3}\right)$, dan Book Value per Share $\left(\mathrm{X}_{4}\right)$ secara simultan terhadap nilai perusahaan (Y).

\section{f. Uji Asumsi Klasik}

Ada beberapa uji asumsi klasik antara lain sebagai berikut, yaitu :

\section{Uji Normalitas}

Uji normalitas berfungsi sebagai penguji regresi, apakah terdapat variabel pengganggu atau memiliki distribusi normal. (Ghozali, 2011:163).

\section{Uji Multikolonieritas}

Menurut Basuki dan Prabowo (2016:108) alat statistik yang sering digunakan untuk menguji gangguan multikolinieritas adalah dengan menggunakan Variance Inflation Factor (VIF). Nilai VIF adalah alat untuk 
mengukur keeratan hubungan antara variabel bebas (X). Jika nilai VIF pada output SPSS kurang dari 10 maka data dinyatakan bebas dari gejala multikolinieritas. (Wahyudi, 2016:145).

\section{Uji Heteroskedastisitas}

Menurut Basuki dan Prawoto (2016:104) deteksi heterokedastisitas dapat dilakukan dengan metode scatterplot dengan memplotkan nilai ZPRED (nilai prediksi) dengan SRESID (nilai residual).

\section{Uji Autokorelasi}

Uji autokorelasi berfungsi untuk menguji apakah didalam penelitian ini terdapat korelasi antara periode ke-t dengan periode t-1 (sebelumnya), apabila terdapat korelasi dapat dikatakan ada problem autokorelasi (Ghozali, 2011:110).

\section{HASIL DAN PEMBAHASAN}

\section{TABEL IV}

HASIL KESELURUHAN METODE ANALISIS

\begin{tabular}{|c|c|c|c|c|c|c|}
\hline \multirow{2}{*}{ Variabel } & \multirow{2}{*}{ Regresi } & \multicolumn{2}{|c|}{ Korelasi } & \multirow{2}{*}{$\underset{\mathbf{r}^{2}}{\text { Adj }}$} & \multirow{2}{*}{ Uji t } & \multirow{2}{*}{ Uji F } \\
\hline & & Parsial & Berganda & & & \\
\hline ROE (X1) & 1,157 & 0,886 & \multirow{4}{*}{0,940} & \multirow{4}{*}{0,861} & 0,000 & \multirow{4}{*}{0,000} \\
\hline DER (X2) & $-0,863$ & $-0,698$ & & & 0,000 & \\
\hline PER (X3) & 0,524 & 0,812 & & & 0,000 & \\
\hline BVS (X4) & $-0,313$ & $-0,562$ & & & 0,006 & \\
\hline
\end{tabular}

\section{a. Analisis Regresi Linear Berganda}

Dapat diartikan dari persamaan regresi linear berganda diatas yaitu, sebagai berikut :

1) Nilai konstanta sebesar 10,370 yang menjelaskan ROE, DER, PER, dan BVS dianggap konstan atau nol, maka pengaruh nya pada nilai perusahaan adalah sebesar 10,370.

2) Koefisien Return On Equity sebesar 1,157 yang menjelaskan, setiap kenaikan $1 \%$ maka nilai perusahaan naik sebesar 1,157.

3) Koefisien Debt To Equity Ratio sebesar $(-0,863)$ yang menjelaskan, setiap kenaikan $1 \%$ maka nilai perusahaan turun sebesar $(-0,863)$.

4) Koefisien Price Earning Ratio sebesar 0,524 yang menjelaskan, setiap kenaikan satu-satuan rupiah maka nilai perusahaan naik sebesar 0,524.

5) Koefisien Book Value Per Share sebesar (-0,313) yang berarti, setiap kenaikan satu-satuan rupiah maka nilai perusahaan turun sebesar (-0,313). 


\section{b. Analisis Korelasi}

Berikut ini adalah hasil analisis dari masing-masing korelasinya, yaitu:

\section{Korelasi Parsial}

Tingkat hubungan pada setiap variabel independen terhadap variabel dependennya, yaitu :

a) Variabel ROE menunjukkan nilai korelasi sebesar 0,886 yang artinya, tingkat hubungan Return On Equity terhadap nilai perusahaan positif sangat kuat.

b) Variabel DER menunjukkan nilai korelasi sebesar (-0,698) yang artinya, tingkat hubungan Debt to Equity Ratio terhadap nilai perusahaan negatif kuat.

c) Pada variabel PER menunjukkan nilai korelasi sebesar 0,812 yang artinya, tingkat hubungan Price Earning Ratio terhadap nilai perushaan positif sangat kuat.

d) Variabel BVS menunjukkan nilai korelasi sebesar (-0,562) yang artinya, tingkat hubungan Book Value per Share terhadap nilai perusahaan negatif sedang.

\section{Korelasi Berganda (Simultan)}

Korelasi berganda dalam penelitian ini yaitu sebesar 0,940. Artinya tingkat hubungan secara simultan ROE (Return On Equity), DER (Debt To Equity Ratio), PER (Price Earning Ratio), dan BVS (Book Value Per Share) terhadap nilai perusahaan pada sektor perbankan periode 2013-2017 positif sangat kuat.

\section{c. Uji Koefisien Determinasi $\left(\mathbf{r}^{2}\right)$}

Uji koefisien determinasi tercantum pada Adjusted $R$ Square yaitu sebesar 0,861 yang berarti, pengaruh ROE, DER, PER, dan BVS secara serentak terhadap nilai perusahaan ialah sebesar $86,1 \%$.

\section{d. Uji t (Parsial)}

Berdasarkan tabel diatas dapat dijelaskan uji t pada setiap variabel independen, yaitu:

1) Return On Equity (ROE)

Hasil pengujian menunjukkan nilai signifikan 0,000 yang lebih kecil dari tingkat signifikan 5\%. Atinya pengaruh ROE terhadap nilai perusahaan adalah postif signifikan.

2) Debt to Equity Ratio (DER)

DER menunjukkan nilai dengan signifikan 0,000 yang lebih kecil dari 5\%.

Artinya pengaruh DER terhadap nilai perusahaan adalah negatif signifikan.

3) Price Earning Ratio (PER) 
PER menunjukkan nilai signifikan 0,000 yang lebih kecil dari 5\%. Artinya pengaruh PER terhadap nilai perusahaan adalah positif signifikan.

4) Book Value per Share (BVS)

BVS menunjukkan nilai signifikan 0,006 yang lebi kecil dari tingkat signifikan 5\%. Artinya pengaruh BVS terhadap nilai perusahaan adalah negatif signifikan.

\section{e. Uji F (Simultan)}

Berdasarkan hasil pengujian tabel diatas, dijelaskan bahwa nilai signifikan 0,000 yang berarti lebih kecil dari 5\% atau 0,05. Artinya secara serentak ROE (Return On Equity), DER (Debt to Equit Ratio), PER (Price Earning Ratio), dan BVS (Book Value per Share) berpengaruh signfikan terhadap nilai perusahaan.

\section{f. Uji Asumsi Klasik}

Berikut ini adalah masing-masing hasil dari pengujian untuk uji asumsi klasik, yaitu:

\section{Uji Normalitas}

Untuk melihat atau mendeteksi distribusi normalitas pada penelitian ini, penulis menggunakan:

\section{NORMALITAS P-P PLOT}

GAMBAR I

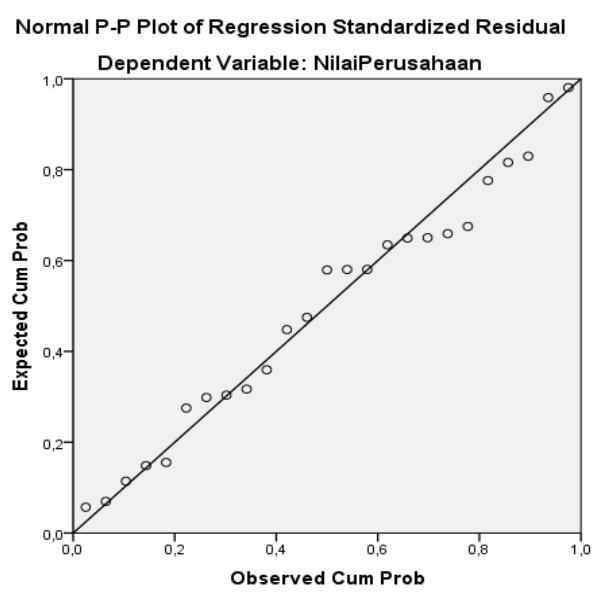

Sumber : Output Spss (data olahan 2019)

Pada gambar diatas menunjukkan data menyebar disekitar garis dan mengikut arah garis, dapat disimpulkan artinya data dalam penelitian ini mempunyai distribusi normal. 


\section{Uji Multikolonieritas}

Berikut ini ialah hasil pengujian dari uji multikolonieritas, yaitu :

\section{TABEL V}

COEFFICIENT

\begin{tabular}{|l|l|l|l|l|}
\hline \multirow{2}{*}{ Variabel } & \multicolumn{2}{|c|}{$\begin{array}{c}\text { Collinearity } \\
\text { Statistics }\end{array}$} & \multirow{2}{*}{ Std } & \multirow{2}{*}{ Hasil } \\
\cline { 2 - 3 } & Tolerance & VIF & & \\
\hline ROE &, 899 & 1,113 & 10 & Bebas gejala multikolonieritas \\
\hline DER &, 530 & 1,888 & 10 & Bebas gejala multikolonieritas \\
\hline PER &, 627 & 1,596 & 10 & Bebas gejala multikolonieritas \\
\hline BVS &, 414 & 2,416 & 10 & Bebas gejala multikolonieritas \\
\hline
\end{tabular}

Sumber : Ouput SPSS dan hasil kesimpulan (data olahan 2019)

Berdasarkan tabel tersebut, tidak terdapatnya variabel independen yang nilai tolerance nya lebih kecil 0,10 yang berarti, tidak adanya korelasi antar variabel independen. Begitu pula pada nilai VIF yang menampilkan hasil sama dengan tolerance, dimana tidak adanya variabel bebas yang memiliki nilai VIF kurang dari 10. Dapat disimpulkan tidak ada multikolonieritas antar variabel independen.

\section{Uji Heterokedastisitas}

Berikut ini adalah hasil uji heterokedastisitas pada output SPSS, yaitu :

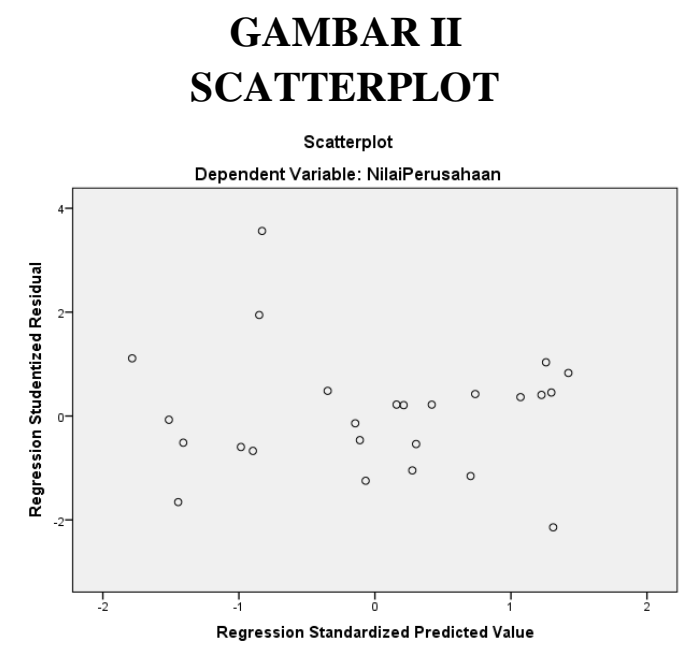

Sumber : Output SPSS (data olahan 2019)

Dapat disimpulkan dari hasil uji heterokedastisitas diatas bahwa tidak ada penumpukan dari data dalam penelitian ini artinya, tidak ada data yang sejenis atau tidak terdapat penyakit heterokedastisitas. 


\section{Uji Autokorelasi}

Nilai Durbin Witson (DW) yang didapatkan sebesar 1,508. Pada penelitian ini, uji autokorelasi menguji secara manual keputusan dari hipotesis, yang terdapat pada pedoman tabel Durbin Witson (DW). Perlu diketahui populasi $(\mathrm{n}=45)$, variabel independen $(\mathrm{k}=4)$, batas atas $(\mathrm{du}=$ $1,7200)$, dan batas bawah $(\mathrm{dl}=1,3357)$, yang dijelaskan sebagai berikut :

TABEL VII

HASIL UJI HIPOTESIS DW (DURBIN WITSON)

\begin{tabular}{|c|c|c|c|}
\hline No & Nilai Pedoman DW & Hasil Uji & Keputusan \\
\hline \multirow{2}{*}{1} & $\mathrm{dU}<\mathrm{d}<4-\mathrm{dU}$ & $\begin{array}{c}1,7200<1,508<4-1,7200 \\
=1,7200<2,309<2,28\end{array}$ & $\mathrm{X}$ \\
\hline \multirow{3}{*}{2} & $0<\mathrm{d}<\mathrm{dL}$ & $0<1,508<1,3357$ & $\mathrm{X}$ \\
\cline { 2 - 4 } & $\mathrm{dL} \leq \mathrm{d} \leq \mathrm{dU}$ & $1,3357 \leq 1,508 \leq 1,7200$ & $\begin{array}{c}\text { Terima } \mathbf{H}_{1} \text { (Ada } \\
\text { Autokorelasi } \\
\text { Positif) }\end{array}$ \\
\hline \multirow{3}{*}{3} & $4-\mathrm{dU} \leq \mathrm{d} \leq 4-\mathrm{dL}$ & $\begin{array}{c}4-1,7200 \leq 1,508 \leq 4-1,3357 \\
=2,28 \leq 1,508 \leq 2,6643\end{array}$ & $\mathrm{X}$ \\
\cline { 2 - 4 } & $4-\mathrm{dL}<\mathrm{d}<4$ & $\begin{array}{c}4-1,3357<1,508<4 \\
=2,6643<1,508<4\end{array}$ & $\mathrm{X}$ \\
\hline
\end{tabular}

Sumber : Hasil perhitungan manual dan keputusan (data diolah 2019)

Dapat disimpulkan dari tabel diatas bahwa nilai yang diuji dengan tabel pedoman DW dengan keputusan hipotesis $\mathrm{H}_{0}$ ditolak dan menerima $\mathrm{H}_{1}$, yang berarti terdapat autokorelasi positif pada model regresi penelitian ini.

\section{KESIMPULAN DAN SARAN}

Berdasarkan dari seluruh hasil analisis yang telah peneliti lakukan mengenai judul "Pengaruh Return On Equity (ROE), Debt To Equity Ratio (DER), Price Earning Ratio (PER), dan Book Value per Share (BVS) Terhadap Nilai Perusahaan Pada Sektor Perbankan Yang Terdaftar di BEI periode 2013-2017”, berikut adalah kesimpulan yang diperoleh, yaitu :

1) Analisis Regresi Berganda

Hasil analisis regresi berganda didapatkan Nilai Perusahaan $=\mathbf{1 0 , 3 7 0}+$ 1,157ROE - 0,863DER + 0,524PER - 0,313BVS.

2) Hasil analisis korelasi terbagi menjadi 2 bagian, yaitu sebagai berikut :

a. Korelasi Parsial, secara parsial hubungan setiap variabel independen terhadap variabel dependen sebagai berikut: ROE menunjukkan nilai sebesar 0,886 (positif sangat kuat), DER menunjukkan nilai $(-0,698)$ (negatif kuat), PER menunjukkan nilai 0,812 (positif sangat kuat), dan BVS menunjukkan nilai $(-0,562)$ (negatif sedang).

b. Korelasi Berganda, secara serentak nilai korelasi berganda yang di dapat sebesar $\mathrm{R}=0,940$ (positif sangat kuat). 
3) Koefisien Determinasi $\left(r^{2}\right)$

Hasil penelitian pada nilai koefisien determinasi pada Adjusted $R$ Square sebesar 0,861 .

4) Uji t (Parsial)

Adapun hasil dari penelitina uji t yang akan dijelaskan pada setiap variabelnya, yaitu :

a. ROE berpengaruh positif terhadap nilai perusahaan, atau keuntungan yang dihasilkan untuk nilai perusahaan itu baik.

b. DER berpengaruh negatif terhadap nilai perusahaan, atau hutang yang dihasilkan pada nilai perusahaan terlalu banyak.

c. PER berpengaruh positif terhadap nilai perusahaan, atau laba yang digambarkan pada harga untuk nilai perusahaan itu baik.

d. BVS berpengaruh negatif terhadap nilai perusahaan, atau kekayaan bersih yang diterima dalam satu saham teralu sedikit.

5) Uji F (Simultan)

ROE, DER, PER, dan BVS berpengaruh positif signifikan terhadap nilai perusahaan secara bersamaan.

\subsection{Saran}

Berdasarkan hasil kesimpulan yang telah diperoleh peneliti, terdapat saran yang peneliti akan berikan, yaitu :

a. Bagi investor, agar lebih teliti lagi dalam mengambil keputusaan untuk menentukan perusahaan yang akan dijadikan sarana investasi dan perlu untuk memperhatikan faktor lain.

b. Bagi perusahaan, dari hasil penelitian ini peneliti memberikan informasi untuk perusahaan perbankan dalam hal berpengaruhnya Return On Equity (ROE), Debt to Equity Ratio (DER), Price Earning Ratio (PER), dan Book Value per Share (BVS) terhadap nilai perusahaan yang dimana, hasil penelitian ini menyebutkan terlalu banyaknya hutang membuat nilai perusahaan nampak tidak baik maka dari itu diusulkan agar perusahaan perbankan dapat mengurangi hutangnya, dan terlalu sedikitnya aktiva bersih yang di dapatkan investor dalam sejumlah lembar sahamnya juga dapat memperburuk nilai perusahaan. 


\section{Daftar Pustaka}

Basuki, Agus Tri dan Nano Prawoto; 2016; Analisis Regresi Dalam Penelitian. Ekonomi \& Bisnis, Edisi Pertama; Cetakan Pertama; Rajawali Pers; Jakarta.

Brigham dan Houston; 2010; Dasar-dasar Manajemen Keuangan (Buku 1); Edisi 11; Jakarta; Salemba Empat.

Fahmi, Irham; 2015; Pengantar Manajemen Keuangan; Alfabeta; Bandung.

Ghozali, Imam; 2011; “Aplikasi Analisis Multivariate Dengan Program SPSS”; Universitas Diponegoro; Semarang.

Harton, Jogiyanto; 2016; Teori Portofolio Dan Analisis Investasi; Edisi Kesepuluh; BPFE-Yogyakarta; Yogyakarta.

Harmono; 2015; Manajemen Keuangan Berbasis Balanced Scorecard Pendekatan Teori, Kasus, dan Riset Bisnis; Cetakan keempat; Bumi Aksara; Jakarta.

Husnan, Suad dan Enny Pudjiastuti; 2015; Dasar-Dasar Manajemen Keuangan; Edisi Ketujuh; UPP STIM YKPN; Yogyakarta.

Harahap, Sofyan Syafri; 2010; “Analisis Kritis atas Laporan Keuangan; Cetakan kesebelas; Raja Grafindo Persada; Jakarta.

Kamaludin, dan Indriani Rini; 2012; Manajemen Keuangan; Edisi Revisi; Mandar Maju; Bandung.

Kasmir; 2013; Analisis Laporan Keuangan; Raja Grafindo Persada; Jakarta.

Kasmir; 2013; Dasar-dasar Perbankan; Raja Grafindo Persada; Jakarta.

Kasmir; 2015; Analisis Laporan Keuangan; Raja Grafindo Persada; Jakarta.

Mardani, Wilysa; 2000; Thesis ''Hasil Analisis Laporan Keuangan Sebagai Dasar Pertimbangan Pengambilan Keputusan”; Universitas Satygama; Jakarta. (Referensi).

Prihadi, Toto; 2012; Analisis Laporan Keuangan Lanjutan Proyeksi dan Valuasi; PPM; Jakarta.

Prastowo, Dwi; 2002;Analisis Laporan Keuangan; Catatan kedua; UPP AMP YKPN; Yogyakarta.

Rio, Irvanda; 2017; Skripsi “Analisis Pengaruh ROA, DER, NPM, dan PBV Terhadap Return Saham PT. Indocement Tunggal Prakarsa Tbk. Periode 2009-2016; Politeknik Negeri Semarang; Semarang. (Referensi).

Sugiyono; 2013; Metode Penelitian Bisnis; Alfabeta; Bandung. 
Sugiyono; 2014; Metode Penelitian Pendidikan Pendekatan Kuantitatif, Kualitatif dan $R \& D$; Alfabeta; Bandung.

Sunariyah; 2006; Pengantar Pengetahuan Pasar Modal; Yogyakarta.

Tandelilin, Eduardus; 2010; Portofolio dan Investasi Teori dan Aplikasi; Edisi pertama; Kanisius; Yogyakarta.

Tri Wahyudi, Setyo; 2016; Konsep dan Penerapan EKONOMETRIKA menggunakan EVIEWS; PT RajaGrafindo Persada; Jakarta.

Abdul Muid, Moch. Ronni Noerirawan; 2012; "Pengaruh Faktor Internal dan Eksternal perusahaan terhadap Nilai Perusahaan”; Jurnal Akuntansi Vol.1 No.2, hal.4

Muhammad Faishal Kahfi, dkk; 2018; "Pengaruh CR, DER, TAT, dan ROE Terhadap Nilai Perusahaan (Studi Kasus Pada Perusahaan Manufaktur Sektor Food and Beverage Yang Terdaftar Di Bursa Efek Indonesia Pada Tahun 20112016)"; e-Proceeding of Management Vol.5, No.1 Maret 2018 (ISSN: 23559357).

Ni Luh Devianasari, Ni Putu Santi Suryantini; 2015; "Pengaruh PER, DER, DPR Terhadap Nilai Perusahaan Pada Perusahaan Manufaktur Yang Terdaftar Di Bursa Efek Indonesia”; E-Jurnal Manajemen Unud, Vol. 4, No. 11, 2015: 3646-3674; ISSN : 2302-8912.

Setiawan, Herry, dkk; 2016; "Pengaruh Return On Asset, Return On Equity, Book Value, Operating Profit Margin dan Debt To Equity Ratio Terhadap Harga Saham Perusahaan Sektor Perkebunan Yang Terdaftar di BEI Periode 20112015; Jurusan Akutansi, Fakultas Ekonomu, Universitas Maritim Raja Ali Haji; Kepulauan Riau.

Julianti, Dewi; 2015; Pengaruh Rasio Hutang dan Profitabilitas Terhadap Nilai Perusahaan (PBV) Studi Kasus Pada Perusahaan manufaktur Sub Sektor Otomotif dan Komponen Yang Terdaftar di BEI periode 2012-2014; Universitas Komputer Indonesia; jbptunikompp-gdl-dewijulian-35457-10unikom_d-I.pdf. 